\title{
Governance in Flanders' regional policy: subregional platforms as development coalitions
}

Governance in het Vlaamse regional-economisch beleid: streekplatformen als groeicoalities

\section{Peter Cabus}

\section{(2) OpenEdition}

\section{Journals}

Electronic version

URL: http://journals.openedition.org/belgeo/15747

DOI: $10.4000 /$ belgeo. 15747

ISSN: 2294-9135

Publisher:

National Committee of Geography of Belgium, Société Royale Belge de Géographie

Printed version

Date of publication: 30 September 2002

Number of pages: 277-294

ISSN: 1377-2368

\section{Electronic reference}

Peter Cabus, « Governance in Flanders' regional policy: subregional platforms as development coalitions », Belgeo [Online], 3 | 2002, Online since 01 October 2002, connection on 19 April 2019. URL : http://journals.openedition.org/belgeo/15747 ; DOI : 10.4000/belgeo.15747

This text was automatically generated on 19 April 2019

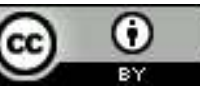

Belgeo est mis à disposition selon les termes de la licence Creative Commons Attribution 4.0 International. 


\title{
Governance in Flanders' regional policy: subregional platforms as development coalitions
}

\author{
Governance in het Vlaamse regionaal-economisch beleid: streekplatformen als \\ groeicoalities
}

Peter Cabus

\section{Introduction}

Engagement and involvement of the citizenry has become a core element of the policy making process. At the same time, regional policy is shifting from providing support only to lagging regions, towards development and promotion of every region within a country. Through this movement in Flanders and in other countries, such as Germany, Sweden and France (for a more detailed discussion see, e.g., Cabus \& Hess, 2000), new forms of geographically defined regional organizations were established in order to mobilize local actors. Typically, these local actors include traditional political actors and non-traditional social partners comprising environmental groupings and socially and economically engaged organizations.

2 A local focus became the rule in setting up regional economic policy, with different intermediate structures created to respond to new economic challenges. These developments occur at a sufficiently low territorial level to make horizontal cooperation possible.

3 In order to achieve this necessary horizontal coordination, national authorities decentralize their competencies through existing or new infranational territorial structures. These structures have to realize policy governance. They are stimulated to act responsibly because they are required to generate at least a portion of the financial means. Overlapping (institutional) networks (leading to «institutional thickness») are supposed to play an important role within this form of governance (Cooke, 1993). While 
traditional instruments (such as grants and investment support) continue to operate, both geographical accents and objectives are more selective, with a greater emphasis on Small and Medium sized Enterprises (SME) (Yuill, Batchler \& Wishlade, 1997).

This article brings together the core elements of governance and of new regional policy. It establishes current regional policy, and especially the subregional development coalitions in Flanders, as part of a governance system. At the same time, it is more sceptical over the real impact of the development coalitions on economic processes. It establishes that territorial identification is a more tangible outcome of the process. Hypothesized localized knowledge spillovers seem to be academic wishful thinking.

5 The first section of this paper describes and links governance to development coalitions and the global-local discourse. At the same time, it critically assesses this discourse. The second section provides an overview of the major developments in regional policy at the EU level before shifting focus to the subregional development coalitions in Flanders. In the third section, the development coalitions are evaluated from a governance point of view and through a critical assessment of global-local theory. The conclusions follow in the final section.

\section{Governance, regional policy and global-local discoursE (I)}

\section{Governance}

Governance has become a central topic among policy makers, where an international consensus is held that policy making is evolving from traditional top-down government towards a system of governing in which a key focus is engaging the citizens within an area.

7 The OECD (2000) regards the engagement of citizens in policy making as a sound investment and a core element of governance. It improves the quality of decision-making and contributes to building public trust in government, raising the quality of democracy and strengthening civic capacity. The first stage in engaging citizens involves information. The next stage involves consultation, with the final stage of active participation seen to be beyond a new frontier yet to be crossed. For the OECD, responsibility for the final decision or policy formulation within this model of engagement rests with the government. Engagement of citizens is therefore by no means a substitute for political responsibility.

8 The White Paper on European Governance (European Commission, 2001) takes as one of its major starting points the complexity of the system as a major cause of people's distrust of institutions and politics. The White Paper proposes opening up the policymaking process to involve more people and organizations in shaping and delivering $\mathrm{EU}$ policy. From this perspective, «Governance means rules, processes and behaviour that affect the way in which powers are exercised at European level, particularly as regards openness, participation, accountability, effectiveness and coherence» (European Commission, 2001, p. 8).

This EU definition does not apply only at the European level. The last four qualities in the EU definition are of great importance. This paper will focus on the first two in particular.

Participation clearly refers to the OECD objective of engaging citizens in the policy making process. Accountability is already more difficult. If participation is reduced to information, 
responsibility is reduced to traditional political responsibility. It is perhaps the first step in a system of governance, and a system of information transfer needs to be established, but this in no way equates with governance.

11 The question arises of how to organize the active participation of citizens in order to carry out the intention of crossing the new frontier. Active participation is very difficult to organize without structuring citizens' engagement. In this respect, the participation of non-political actors in society is usually the blueprint for engagement. These actors, often referred to as the living forces, consist of labour unions and employer organizations. Their participation reflects a tradition in The Netherlands and Belgium of engaging social partners (unions and employers organizations) in the policy making process. The concept of concertation economy established in both countries following World War II, refers to an almost continuous process of consensus-oriented consultation between employers' associations and trade unions (bipartite), and between these social partners and the government (tripartite). Therefore, government and social partners share responsibilities in the field of social and economic policy.

\section{Global-local discourse and regional policy}

New theoretical insights into regional development are emerging from a focus on the role of the «local» in local economic development within a discourse on the global-local nexus. In its essence the global-local hypothesis proposes that the more something functions on a global scale, the more it seems to require a set of conditions that are local, immobile and specific in nature. Specific, locally bound conditions would play a decisive role in the development of different territories (Swyngedouw, 1989; Porter, 1998) because these are integrated in corporate strategy.

In a synthesis of the global-local debate, Cabus $(1999,2001)$ provides an overview of the different theoretical models that can be distinguished. The most developed group of models considers the region not so much as the centre of local economic development, but as a centre of knowledge in a process of territorial learning. As a result, these models focus on untraded interdependencies.

These models have their roots in the Italian industrial districts, on the one hand, and the territorial high-technology complexes, on the other, with Silicon Valley being the most important example. These two basic models are explained by using traditional agglomeration theory and the existence of a specific local culture (e.g., Piore \& Sabel, 1984; Becattini, 1992; Belussi, 1996; Porter, 1998). A new stream of literature has emerged from these two roots that no longer emphasizes agglomeration economies in a traditional way, but rather in terms of an accumulation of knowledge made possible by specific socio-cultural conditions (e.g., Asheim, 1998 and 1999; Storper, 1999; Markusen, 1997). Within the mechanism of socio-cultural capitalization, proximity is conceived from a physical (time geography, i.e., the time needed to go from one place to another) as well as from a socio-cultural point of view. Defined this way, the advantage of proximity is translated as an agglomeration of companies, institutions and other social entities, linked together in a learning process and creating social and cultural capital. In turn, this process attracts other economic activities (Malmberg and Maskell, 1997).

The global-local discourse indicates the importance of mobilizing local actors to counterbalance global economic forces. In this respect, the discourse becomes a theoretical justification for a governance approach in regional policy. The regional policy 
field has come to be regarded as a contemporary governance laboratory. Within this context, it is argued that the establishment of a new type of decision-making process resulting in development coalitions (Asheim, 1998) is typical. The main task of these coalitions is to counterbalance the former top-down approach, in which there are strong hierarchical relationships, with an important bottom-up (local) input in order to grasp global economic forces. Subsidiarity is a mainstream element behind this evolution.

Networking between local governmental, scientific, political as well as non-traditional non-political actors is essential in development of coalitions. They are not traditional in the sense that they have no political responsibility, but they are supposed to have a type (social, economic, environmental) of representative function for a region. From this point of view, regional development is primarily a social process, and as a consequence, development is also a territorial process linked to the social capital within the territory.

\section{Critique}

17 The politically amenable character of the global-local discourse is certainly one of the driving forces behind the ascendancy of governance in regional development. It provides local politicians with an external enemy (the global) and a solution (the mobilization of local actors in development coalitions). When drawing general conclusions from the French experiences of local economic development, Merenne-Schoumaker (1996) argues that she sees not models of local development but rather political projects supported by local actors. She draws attention to the possible danger of these models creating a false sense of security, because they give the illusion that mobilizing local actors can lead to some form of control over global processes.

18 A second critique deals with the significance of untraded against traded/market interdependencies. Within global-local theory, untraded interdependencies are regarded as a crucial mechanism in territorially bound geographical knowledge spillovers. The question is whether or not this is really the key mechanism for separating regions with successful development from others.

Cabus (2001) pointed to the fact that with regard to knowledge, a fundamental distinction must be drawn between information and knowledge that is generally available, on the one hand, and strategic knowledge as a production factor, on the other hand. In the New Growth Theory, no clear distinction is made between the two. It is reasonable to expect that generally available information and knowledge can play roles in the development of a region and social capitalization. In this context, the overall local social and cultural climate, as well as the roles of government and other institutions (Borja and Castells, 1999), can play an important role in the economic development of a certain area by improving conditions for the circulation of ideas. Hepworth and Ryan (1997) see a role here for information partnerships; large enterprises should be persuaded to share their processes of knowledge creation with actors outside the firm (students, the unemployed, SMEs, social groups and government). However, the authors admit that there is little knowledge of the social dynamics necessary to achieve these partnerships.

The logic is clearly different in the case of strategic knowledge, where it is unlikely that firms concerned will be willing to share it with a local community, because it is precisely the foundation of their competitive advantage. Therefore, this type of knowledge will only be shared (e.g., within scientific milieus, or in a production process based on coreactivities and outsourcing) if sharing creates an additional competitive advantage for the 
firm concerned. In this debate it is essential to draw attention to the evolution within the network enterprise towards equal partnerships based on balanced strategic control (e.g., trends in the Belgian automobile industry-see, e.g., Cabus, 1999).

In connection with the argumentation developed above, using detailed data on California biotechnology, Zucker et al. (1998) proved that indeed the positive impact of research universities on nearby firms relates to identifiable market exchange between particular university star scientists and firms, and not to generalized knowledge spillovers within the territory. The scientists concerned do not give away to enterprises the fruits of their intellectual human capital, but instead enter into contractual arrangements with existing firms within commuting range from the university. In this way, Zucker and associates see that what appeared to others as a case of knowledge spillovers is in fact a standard case of market exchange of rivalrous and excludable goods.

A third critique relates to the democratizing influence of development coalitions. According to Swyngedouw's (1996) analysis of governance structures that were set up in the province of Limburg (Belgium) to accompany the closing of the mines, this movement characterizes the traditional state that is not adapted to increasing territorial competition. The state of the citizen is replaced by a technocratic-managerialentrepreneurial state, at scales different from those at the traditional national stage. Typical of the new policymaking is the rivalry between different groups in society, and thus the absence of a hegemonic territorial vision of future development. This, in turn, undermines territorial cohesion, discourages external investments, and slows down the whole process of development.

The undertone of this appreciation is doubly negative. First, governance is organized by new local development coalitions with global connections (in the words of Swyngedouw a «glocal» elite) ${ }^{1}$, selling their territory in a global economy. As such this is not negative, but these coalitions tend to exclude the socially, economically and politically more vulnerable sections of society. Secondly, there is no democratic control over the process because decision-making is delegated from a democratically controlled government to technocratic, locally organized networks.

These three critiques suggest that local/regional development coalitions: (1) have to be positioned within existing relationships of (political) power, and (2) only have the potential to be effective if they commence on the assumption that the rules of the game are defined more by the market than by supposed untraded interdepend-encies.

25 I have established that the global-local discourse is the theoretical justification for a governance approach in regional policy. Considering the related critiques, the next question is: which elements of this discourse are actually used in the practice of governance? I hypothesize that the urban and regional governance mechanisms/ agencies/coalitions are perhaps influenced most by Business School /corporate «branding» in the marketing and identity formation of a locality.

In the next section, after a brief overview of the major developments in the EU's regional policy, I study the subregional platform policy in Flanders. I shall test the stated hypothesis and establish whether or not the critiques are applicable. I do this from the position of a favoured witness. Being a civil servant in the Flanders social and economic council ${ }^{2}$, I shared responsibility for the introduction of the platform system and could follow its development from my first-hand involvement. 


\section{Regional policy in Europe and in Flanders}

\section{Major developments in European regional policy}

In 1975, a framework for a more active regional policy was created in order to address growing disparities among the European regions. After the introduction of a specific regional policy in the Community, and the first steps in this field having been made, new priorities, means and actions were developed in different stages (European Commission, 1999a). The last one was introduced with «Agenda 2000», which was politically approved at the Berlin summit in March 1999 (European Commission, 1999b).

There were a number of significant steps in these successive changes of European regional policy. First, there was a substantial increase of the financial resources ${ }^{3}$. Next, these increased financial means were focussed both on priority fields (objectives) and on regions and areas. In the programmes running from 2000 until 2006, there remain two territorially focused objectives. Objective 1 promotes the development and structural adjustment of those regions where development is lagging behind. Objective 2 supports the economic and social conversion of areas facing structural difficulties, including economic and social change in the industrial and service sectors, declining rural areas, urban areas in difficulty and depressed areas dependent on fisheries. Regions that were eligible in the former period 1994-2000, but are no longer eligible today, have a phasingout system. The included map (Figure 1) indicates the current situation in Belgium.

Figure 1. EU-regional policy: Eligible regions in Belgium 2000-2006.

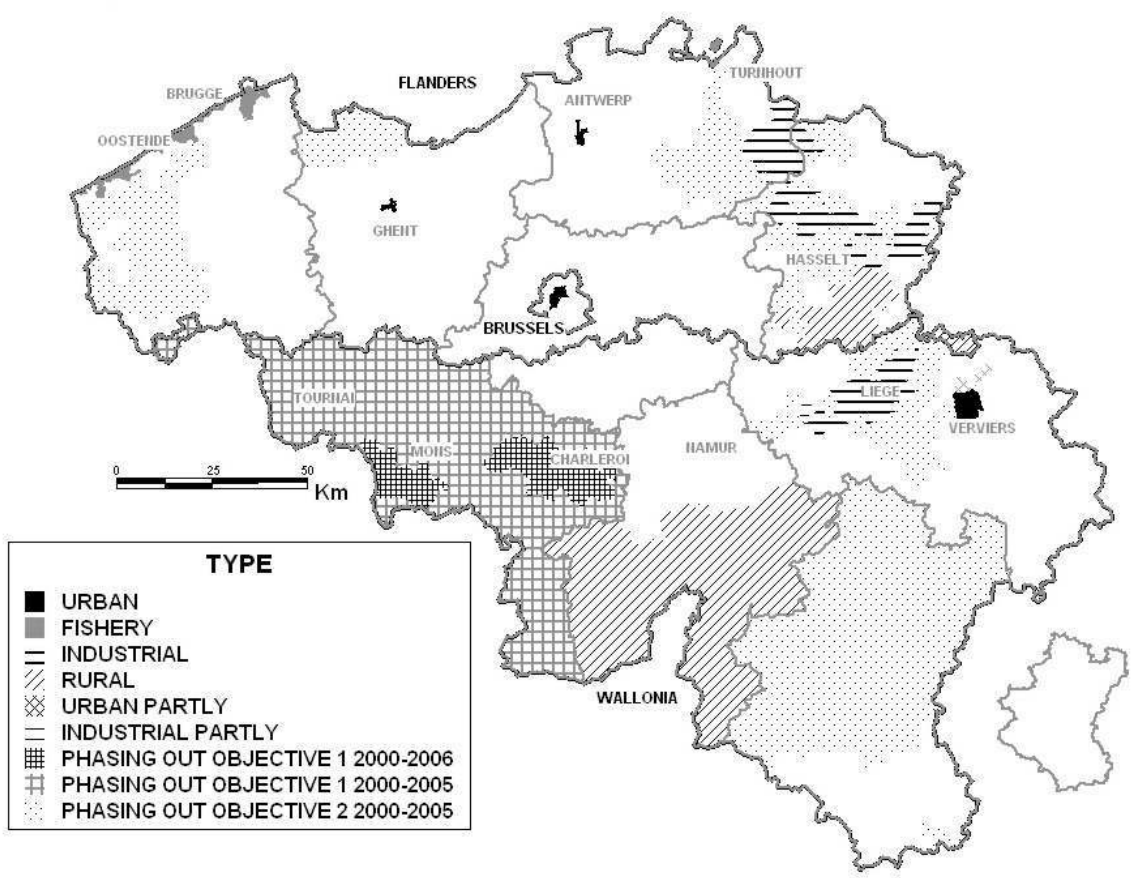

The project-based approach was also abandoned for a programme-based approach with an increased partnership between the European Community, the Member States and the Regions. This was based on the principle of subsidiary that was introduced in 1992 through the Treaty of Maastricht. Finally, a clear-cut future vision on a common regional 
policy has been developed, which is partially related to securing the resources for a European approach via Community Initiatives that focus on innovative actions. There are 4 Community Initiatives (CIs): Interreg III (cross-border, transnational and interregional cooperation); Leader + (focussing on rural development); Urban II (supporting innovative strategies to regenerate cities and declining urban areas); and Equal (elimination of factors leading to inequalities and discrimination in the labour market).

Despite all these new accents, European Regional Policy so far has focussed on regions whose development is lagging behind and on declining industrial regions. Geographically speaking, as in the Flanders case, the impact of these programmes is clearly marginal, which raises questions over the usefulness of this policy.

31 From the governance point of view, the engagement of citizens remains rather fuzzy. There is indeed a growing partnership between the European Community, the Member States and the Regions in the regional programs. Is this growing partnership really making European regional policy more transparent? Indeed this policy remains very topdown oriented. In addition, it is expected that in the near future, when new countries enter the Union, this type of policy will no longer make sense in Belgium because there will no longer be eligible regions. It is clear that when the next programme begins in 2007, the presence of new Member States, composed almost entirely of regions requiring economic development support, will necessitate a redoubling of efforts in order to achieve a timely and significant catching up (European Commission, 2001b).

This does not mean there will be no real need for regional policy in Belgium, because regional disparities will still exist. In my view, regional policy is much more than wiping out economic differences. The aim of regional policy consists in engaging every region in a country according to their assets. This goal may become a part of European regional policy, for indeed, alternatives to direct zonings with rigid criteria are being sought (European Commission, 2001b, p 32). It is stated that the programming of the different priority domains would need to be undertaken on the basis of an allocation of resources by Member States, based on population and adjusted by appropriate indicators of socioeconomic conditions.

In my view, it is appropriate that these resources be integrated in the national regional policy. This integration could also guarantee continuity after the resources are exhausted and can enhance, as we will see further on, the local governance structures.

The Community Initiatives have already made progress in terms of governance. For example, Leader, one of the four CIs, became possible with the 1988 reform of the Structural Funding policy. The first program was introduced in 1991 and, thereafter, the Leader II program ran from 1995 to 2000. Now, the Leader + program will run until 2006. In essence, Leader was introduced to stimulate innovative approaches to rural development with small-scale initiatives and at the local level (territories of less than 100,000 inhabitants). Existing or ad hoc LAGs (Local Action Groups) could apply for funds by producing a business plan with actions for development based on the valorization and exploitation of indigenous resources. Whilst the first two Leader programs had been restricted to eligible areas for objectives 1 and $2(5 b)$, all rural areas may participate in the latest program.

Networking, one of the basic elements in engaging the citizen, and the creation of LAGs become central to the rural program. As we shall later see, this has led to new theoretical insights into development models and territorial identification processes (Ray, 2001). 


\section{Regional policy in Flanders: subregional ${ }^{4}$ platforms}

Within the federal state of Belgium, the competence of regional economic policy is decentralized towards the constituent parts of the state (Wallonia, Brussels and Flanders). Regional policy in Flanders (Belgium) dates back to the late fifties and the early sixties. In order to promote industrial development and its equal distribution over Flanders, a traditional system of investment subsidies (that is now covered by the European competition policy via Articles 92a and 92b of the Treaty) and an active policy for the development of industrial estates, was set up. In the nineteen-seventies, Regional Development Agencies (RDAs) were created for each province in Flanders and one for the Walloon region (which has since ceased to exist). As elsewhere, during 1960-1990 regional development was very traditional, and the central question was how to distribute economic prosperity across the country.

In the wake of the new trends and new theoretical developments sketched above, together with realization that EU regional policy had been ineffective in engaging every subregion in Flanders, from 1988 new and renewed attention was given to regional development in Flanders.

The first regional development «impulse» program that ran from 1990 to 1994 remained focussed on lagging regions. Governance was embryonic, but saw the creation of regional managers to create local networks to trigger bottom-up initiatives and mediate between the regions and the Flemish government.

The regional policy we see today was first introduced in 1994 (Flemish Government, 1994) and clearly has a governance approach. Basically, the engagement of the citizen and bottom-up linkages is assured by the installation of development coalitions: the subregional platforms.

40 These platforms spontaneously develop in the regions and its members are the so-called living forces (local politicians together with social partners and other local actors). Through a system of consultation between the subregion, the central administration and the government, a regional charter is effected. This charter includes environmental factors that the region considers to be important for the economic development of the subregion. The Flemish government made the commitment to realize these charters. Regional charters have been realized, or are in the final stages, for the majority of platforms.

41 It is clear that regional policy in Flanders has evolved into a type of governance in which local autonomy plays a substantial role in the development coalition. Indeed, the decree installing the regional platforms creates only a minimum basis. This similarly applies for (i) the definition of the subregion, (ii) the identification of the partners in the platform, and (iii) the building up of the strategic vision and the formulation of the regional charter.

(i) The definition of a subregion - A subregion is a contiguous territorial entity with sufficient internal socio-economic cohesion and critical mass (e.g. inhabitants). It is on this geographical level that the necessary horizontal coordination between local actors and between the policy fields concerned has to be installed. 

provincial scale and the size of the individual platforms ranges from only 100,000 (Meetjes-land) inhabitants to nearly 1 million (Antwerp). Brussels. It is obviously a strong and growing region (Gewestelijke Ontwikkelingsmaatschappij Vlaams-Brabant, 2000) with many spillovers from Brussels. A possible reason for this absence is that the region does not see the necessity to organize itself because development is occurring unaided. It is clear however that the effects are certainly not all positive, one being a severe territorial competition between the core (Brussels) and the periphery (Cabus et al., 1995) in a city regional context. There is also growing traffic congestion and increasing pressure on the environment. Another reason for not creating a platform is perhaps the presence of a well functioning RDA, although there is a platform (Hageland) for the eastern part of the province.

(ii) The partners in the platform - A minimum representation of local politicians (municipalities) and local social partners is required, together with a representative of the Flemish economics and labour administration, and of the local RDA. Other local organizations can join the platform, with the platform itself permitted to choose up to 20 partners. In most cases, environmental groups, together with some more socially oriented organizations, have joined the platforms. The other $50 \%$ has to come from the partners in the platform itself. In many cases, local larger companies (banks, local affiliates of the National Bank, large energy companies) provide local means. In these cases, the company finances the regional manager, an idea introduced with the earlier impulse programme. Often these companies provide the infrastructural requirements (offices). In some cases, the municipalities contribute on a per capita basis. In other cases the local RDA or Chamber of Commerce plays a supporting role.

(iii) Strategic vision and regional charter - The strategic vision is built up in three stages. First, one makes a description of the socio-economic structure of the subregion. The definition of the specific local factors influencing economic development is the core of the strategic vision. In most cases this is performed with a SWOT analysis. Finally, based on the specific local factors, the strategic choices for the subregion are assured via the charter.

48 The platforms have a more or less free hand, especially in the first two stages. This is important because it is in this stage that the anchor points are defined for future development. At the same time, definition of the local factors and making the strategic choices are the toughest part in building up the common local interest. This is not only true because every partner has to be convinced that the choices are defendable for the part of society he or she is representing; consensus must also be reached on the final choices.

In practice, apart from some general points of attention such as infrastructure, the need for industrial estate and the need for a well-educated labour force, these anchor points are indeed specific to the subregion. For instance, the strong points for the Strategic Plan Antwerp (MVPA, 19925) are obviously found within the existent harbour, the important chemical and automobile industrial activities, and the diamond sector. In order to overcome inherent frictions between a large city in the core of a subregion and its 
surrounding municipalities, common interests must be established. Another anchor point is the installation of public/private partnerships to create a more attractive environment for business as well as for visitors and tourism.

Since this is a strongly urbanized region, emphasis is placed on a viable environment and physical planning. Finally, research and development are key factors in the important university infrastructure.

The last stage of formulating the strategic choices in the charter involves a thorough concertation process with the central administration (that is also the reason why representatives are members of the platform). This process is also supervised by a steering committee that represents all concerned central administrations. This consultation process is necessary because all projects resulting from the charter must be implemented by the different responsible administrations ${ }^{6}$. This also means that the platform itself has no power, and no means, to realize its own projects.

Figure 2. Subregional platforms in Flanders.

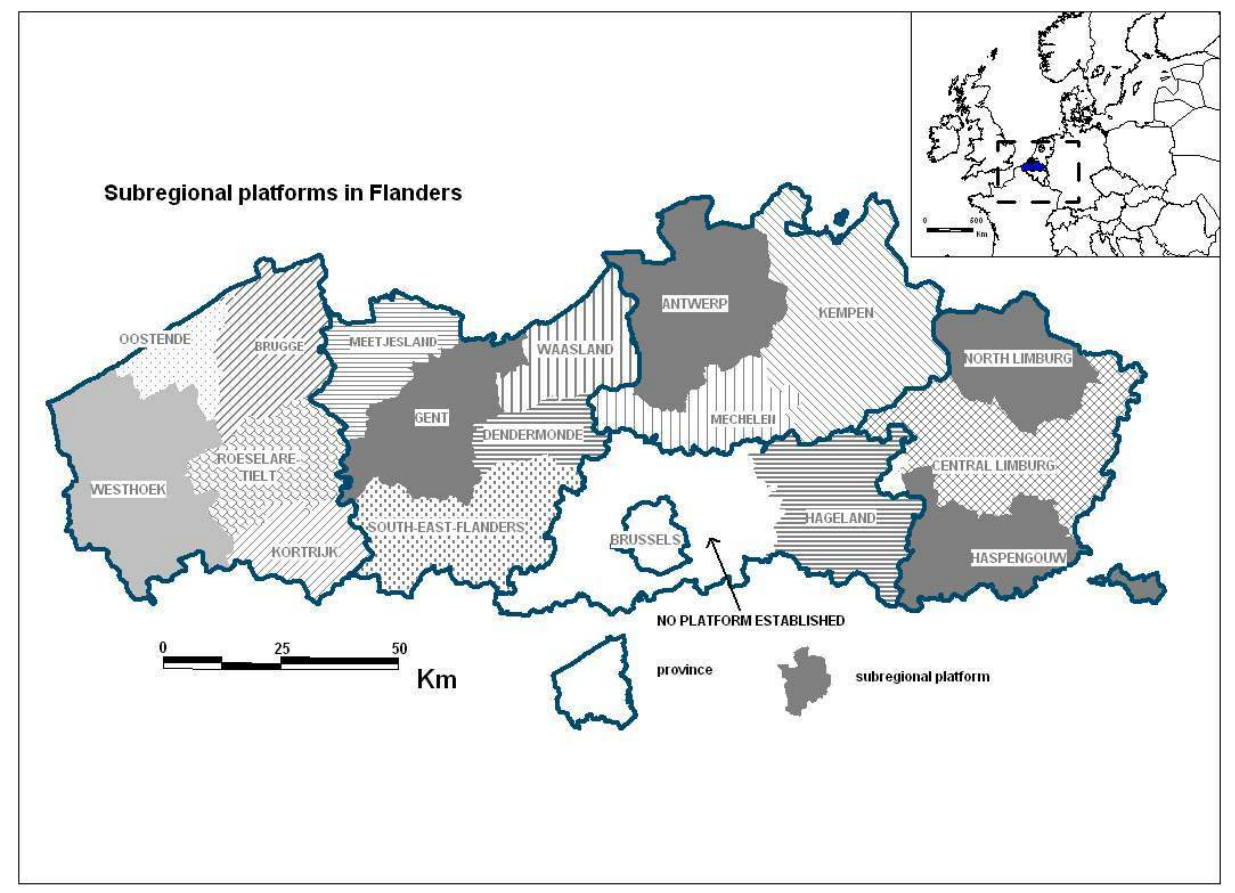

\section{Territorial identification as a condition for development coalitions}

The example of Antwerp has already indicated the need to create common local interests on a territorial basis. This section further investigates this important condition, commencing with a rural context. The rural character of subregional platforms such as the Westhoek, the Meetjesland, Haspengouw, Hageland and South-East Flanders, is prone to considerable pressure from (sub)urbanization. Unsurprising-ly, these five regional platforms emphasize the importance of their rural character for economic development. As part of the strategic vision of Westhoek (Subregional Platform Westhoek, 1998), its mission is to create a Westhoek mentality: «The ambition of the Westhoek is to realise a socioeconomic development respecting the current rural character (tourism, agriculture, recreation) 
and its environmental and ecological qualities (open space, attractive landscape, concentration of housing and industry)».

Reaching this objective requires a specific policy for the countryside in which a noneconomic dimension has been added to economic development. This needs a regional strategy respecting and supporting environmental and ecological dimensions. Rural character is no longer considered a handicap, but a basic condition for economic growth. This growth should rest on agriculture, non-polluting and spatially concentrated industrial development, high technology, tourism and recreation, social profit, viability of villages, and building up relationships with nearby urban areas.

The explicit objective of creating a Westhoek mentality in the Westhoek governance model is particularly intriguing. As in the example of Antwerp (where this mentality is to be created within a city regional context), this model clearly indicates that the local can only seize global processes if all people in the urban or rural region share similar interests and follow the same strategies.

What is clear from these examples is the necessity of basing territorial identification around common values, identifying features and cultural marks. The development coalition can only attain this territorial identification through participative democracy that is widely representative of the citizenry, for whom all this is intended.

\section{Governance, regional policy and global-local discourse (II)}

\section{Subregional platforms as development coalitions and governance} governance system. This weakness also destabilizes the development coalition. Indeed, critics state that the governance structure is nothing more than a chat room.

There are additional questions: Once the charter has been effected, why should the platform continue to exist? How can one continue to mobilize local actors, when they have no real grip on the process itself?

Governance in regional policy should not only imply the organization of local networks, the detection of local specific assets and the creation of bottom-up linkages. It also implies a «certain degree» of decentralization of decision-making power. This really gives citizens, who are supposedly engaged in the policy making process, the feeling of participation. Without a real decentralization of decision-making power, it is perhaps difficult to speak of real development coalitions in Flemish regional policy.

Of course it is not easy to quantify this «certain degree» of decision-making power decentralization. Swyngedouw (1996) makes a point that going too far implies a technocratic solution, with a real risk that the socially, economically and politically more vulnerable groups of society are excluded. In that case, society as a whole will certainly not benefit from this type of governance because of a lack of democratic control over the process. In this respect I concur with the OECD (2000) statement that engagement of the citizenry cannot replace political responsibility. It is necessary to situate emerging governance structures of what is essentially a political project, within an analysis of power relationships. From this viewpoint, one has to be aware that the creation of subregional platforms should be seen as a policy tool for breaking into existing formal 
and informal relationships of power (politicians, administration, RDAs, Chambers of Commerce, unions, etc.). Subsequently, it is normal that the platforms would want to seize their place within these relationships, while existing organizations want to prevent this happening. Indeed, the Chambers of Commerce, and in some cases the RDAs ${ }^{7}$, view the platforms as competitors for the same resources. Cooke (1993) does not necessarily view this competition as a problem. For him, institutional thickness is one of the preconditions for regional development, and as long as the competition between different layers creates added value, this can have positive effects for the region concerned.

In any case, in order to maintain democratic control and political responsibility, the Flemish government itself must necessarily develop a clear-cut vision of the roles of regional policy and stakeholders. In our view, other than RDAs (related to their task) or Chambers (related to the part of society which they represent), a platform structure can make a positive contribution to creating genuine governance and building effective development coalitions. Territorial identification is certainly a precondition for effectiveness. It is also clear that the subregional development coalitions do not represent the entire governance system, but only a part of it.

The budget for regional policy is certainly not important relative to other policy fields. This may change in the future when the EU applies itself to subsidiarity within the field of regional policy, a move that makes the integration of financial resources possible in the Flemish regional policy system. In our view, these resources, together with locally generated resources, should be under the authority of the platforms as regional development coalitions.

Within this governance constellation, subregional platforms can make a positive contribution to establishing genuine citizen participation in the policy making process. If this participation is set up as a form of participatory democracy, then the platforms are really exemplary experiments in governance for other policy fields. In this respect, there is still work to be done, a point that the present Flemish government should keep in mind during its current activities in restructuring regional economic policy.

Ray's (2001) vision of rural regional development can play an inspiring role here. Ray proposes the term «neo-endogenous development»(p. 4), a form of participative democracy, as a new model for local rural development. This model stems from the ongoing work of rural sociologists and his research on the EU's Leader Initiative, involving nearly 1,000 local territorial experiments.

The concept of neo-endogenous development is primarily concerned with focusing on rural territories (both in their geographical and socio-cultural senses), on levels smaller than the national or regional scale. The concept must be viewed as the combination of a territorial identification process, often organized around specific rural products (tourism, landscape, specific agri-food products, «appellation d'origine contrôlée», etc.) and the creation of cultural marks or identifying features with which the territory is «selling itself to itself» and to the outside world.

According to Ray, the neo-endogenous development model focuses internally on the existence of a mode of production subservient (or potentially so) to the dominant (freemarket) mode. In this alternative, subservient mode of production, following Bourdieu's (1986) approach, the collective resources of endogenous development are conceptualized as cultural capital. Cultural capital refers not only to culture in its material state, but also 
to an on-going valorization of the (embodied) culture. The players in a culture economy feed on the cultural capital as a collective resource, and thereby assist in its accumulation. Cultural capital is convertible into economic capital through the individual, and into social capital by reciprocal behaviour.

As noted by Ray $(2001$, p. 2), urban and rural contexts are inextricably interrelated. Indeed, the neo-endogenous model developed within a rural context is also plausible within a non-rural context. As it turns out, his concept of neo-endogenous development constitutes a clear category within the mainstream of global-local models, in which sociocultural capital is considered to be the main driving force. It is clear, however, that he surpasses mainstream thinking by accentuating the essential nature of the creation of common local interests. At this point, he comes to the same conclusion as Cabus (1999, 2001), who adds that localization forces must be seen from the point of view of existing, or absent, common local interests, as well as in terms of the local capacity to organize them. The processes of creation, manifestation and protection of common local interests do not appear to occur as a matter of course. Therefore, from the perspective of the region, local advocacy is essential. As Ray has pointed out, this advocacy has an internal as well as an external component.

\section{Global-local discourse}

We return to the first two critiques formulated earlier with respect to global-local theory. The question driving the resurgence of the subregional platforms and other regional development models on the European level, and in other countries, is: how, from a local point of view, can global processes be grasped? The development coalitions that are the answer to this question, whether or not they are integrated in formal structures, become a part of the governance system of the territory concerned. They win a place within the existing relationships of (political) power and try to attain their common goals.

What is clear, from the examples of both the urban and rural subregions, is the necessity of forming a territorial identification around common values, identifying features and cultural marks, leading to identification of a common local interest to defend in a global world. The development coalition only can reach this territorial identification when it is a form of participative democracy with a wide representation of the citizenry, for whom all this is intended.

In analysing the situation in Flanders from a governance point of view, global-local theory seems to be a basis for political projects, in the sense of mobilizing local actors. Of course it would not be the first time that this theory has been misused when translated into policy. On the other hand, this is perhaps a sound interpretation of the real impact of global-local regional development models on (global) economic processes. The argumentation over the shielding of strategic knowledge, and the example of biotechnology in California, suggest that market relationships are still determining the rules of the game, and not so much the supposed localized knowledge spillovers, which seem more like the wishful thinking of academics. The accent on identifying features suggests that the hypothesis formulated earlier-that the urban and regional governance mechanisms/agencies/coalitions are perhaps more influenced by Business School / corporate «branding» in the marketing and identity formation of a locality-is to be confirmed. 
71 It is established that the cluster model (Porter, 1990) is an attractive alternative regional development policy model. Martin, Sunley and Turner (2002, p. 133) describe the attractiveness of cluster models as their apparent ability to simultaneously promote both the supply and demand sides, by using local networks to break down the knowledge gaps between investors and small firms.

72 Like global-local theory, it is probable that this model has to be put into perspective and «has to carry a public health warning» (Martin and Sunley, 2001). We may add that it is probably no basis for a governance model $^{8}$. In fact, it is not even a model for «local» regional development, in view of the fact that production networks are functioning in a geographical action space that is at least on the scale of Flanders or even of Western Europe (e.g., automobile networks, Cabus, 1999).

Putting the policy translation of the two models together, we can discern wishful thinking not only among academics but also among policy makers. On the other hand, it is clear that the governance approach within regional development is as such worthwhile, even when the «local» impact on economic processes is relative.

\section{Conclusion}

74 This paper has aimed to evaluate subregional platforms in Flanders from a governance perspective, and to critically assess the theoretical basis of the global-local discourse on which they are premised. The conclusion is reached that, if the Flemish government has a clearly defined vision of the role of regional policy, and if a real decentralization of decision making power can be achieved, as development coalitions, these platforms can make a worthwhile contribution to a governance structure that allows citizens to genuinely participate in the policy making process.

It is further established that the territorial identification process is a more tangible outcome of the process. The hypothetical localized knowledge spillovers in global-local theory seem like academic wishful thinking. The evidence gathered suggests that the urban and regional governance mechanisms/agencies/coalitions are significantly influenced by Business School /corporate «branding» in the identity formation and marketing of a locality. From this evidence, it is possible to conclude that policy practice misappropriates global-local theory, although of course the obverse may also be observed. Placing regional development within a governance context makes it, by definition, a political project. From a governance point of view then, global-local theory is indeed a primary basis for political projects, in the sense of mobilizing local actors.

\section{BIBLIOGRAPHY}

ASHEIM B. (1999), Innovation, social capital and regional clusters: on the importance of co-operation, interactive learning and localized knowledge in learning economies, Paper RSA International conference on regional potentials in an integrating Europe, 18-21 September, Bilbao. 
ASHEIM B. (1998), Learning regions as development coalitions: Partnership as governance in European workfare states?, Paper IGU Commission on geography and public administration, 2-5 May 1998, Cambridge.

BECATTINI G. (1992), «Le district marshallien», in BENKO G., LIPIETZ A. (eds.), Les Régions qui gagnent. Districts et réseaux: les nouveaux paradigmes de la géographie économique, Paris, Presses Universitaires de France, pp. 35-55.

BELUSSI F. (1996), «Local systems, industrial districts and institutional networks: Towards a new evolutionary paradigm of industrial economics», European Planning Studies, 4, 1, pp. 5-26.

BORJA J., CASTELLS M. (1999), Local \& Global Management of cities in the information age, London, Earthscan Publications Ltd.

BOURDIEU P. (1986), «The forms of capital», in RICHARDSON J.G. (ed.), Handbook of Theory and Research for the Sociology of Education, New York: Greenwood Press.

BRACZYK H., COOKE PH., HEIDEN-REICH M. (eds.) (1998), Regional innovation systems. The role of governances in a globalized world, Bristol, Pennsylvania, UCL Press Ltd.

CABUS P. (2001), «The meaning of local in a global economy», European Planning Studies, 9, 8/ December 1, p. 1011-1038.

CABUS P. (1999), De geografie van de ondernemingsstrategie. De toelevering aan de Belgische autoindustrie als onderlegger, Doct. Dissertation, Catholic University Leuven.

CABUS P., DE DECKER P., KESTELOOT C., MEERT H. (1995), «Concurrentie of complementariteit? Plannen voor Brussel en omgeving», Ruimtelijke Planning, Kluwer, Katern 4, blz. 7-32.

CABUS P., HESS M. (2000), «Regional politics and Economic patterns: glocalisation and the network enterprise», Belgeo, 1, 2, 3, 4, blz. 79-101.

COOKE P.H. (1993), «Interregional networks for regional innovation: methods, policies, practices», Planologisch Nieuws, 13, 2, pp. 142-156.

EUROPEAN COMMISSION (2001), European governance. White paper, Brussels, June $25^{\text {th }}$.

EUROPEAN COMMISSION (2001b), Second report on economic and social cohesion, Brussels, January 31st.

EUROPEAN COMMISSION (1999a), $6^{\text {th }}$ Periodic report on the regions, Luxembourg.

EUROPEAN COMMISSION (1999b), Agenda 2000.

EUROPEAN COMMISSION (1994), Concurrentievermogen en cohesie: tendensen in de regio's. Vijfde periodiek verslag over de sociaal-economische situatie en ontwikkeling van de regio's in de gemeenschap, Luxemburg.

FLEMISH GOVERNMENT (1994), Decree of 20 July 1994 concerning recognition and subsidization of regional platforms within the framework of the regional economic policy and the conclusion of regional charters, Belgisch Staatsblad (Belgian Monitor) of 21/10/1994.

GEWESTELIJKE ONTWIKKELINGSMAAT-SCHAPPIJ VLAAMS-BRABANT (2000), Vlaams-Brabant op de drempel van de $21^{\text {ste }}$ eeuw.

MAATSCHAPPIJ VOOR DE VERNIEUWING EN DE PROMOTIE VAN ANTWERPEN (MVPA) (1992), Strategisch Plan Regio Antwerpen.

MALMBERG A., MASKELL P. (1997), «Towards an explanation of regional specialization and industry agglomeration», European Planning Studies, 5, 1, pp. 25-41. 
MARKUSEN A. (1997), Regional culture and regional politics as assets and handicaps for innovation, Lecture during the «International Conference on Industry, Innovation and Territory», Lisbon, 20-22 March 1997.

MARTIN R., SUNLEY P. (2001), «Deconstructing clusters: chaotic concept or policy panacea?», Working papers series, WP 244, Centre For Business Research, University of Cambridge.

MARTIN R., SUNLEY P., TURNER D. (2002), «Taking risks in regions: The geographical anatomy of Europe's emerging venture capital market», Journal of Economic Geography, 2, pp 121-150.

MERENNE-SCHOUMAKER B. (1996), «Le développement local: bilan et conclusion», Geographies, Bulletin de l'association de géographes Français, $73^{e}$ année, 5, pp 464-467.

OECD (2000), Citizens as partners: Information, consultation and public participation in policy-making.

OECD (1997), Regional policies in the 90s: The shift towards competitiveness and partnerships with subregional levels.

PIORE M.J., SABEL C.F. (1984), The second industrial divide. Possibilities for prosperity, New York, Basis Books.

PORTER M. (1990), The competitive advantage of nations, The Macmillan Press LTD, London, Basingstoke.

PORTER M. (1998), On competition, Boston, HBS Press.

RAY C. (2001), Culture economies: A perspective on local rural development in Europe, Centre for Rural Economy, Newcastle upon Tyne.

STORPER M. (1999), «The resurgence of regional economies, ten years later: the region as a nexus of untraded interdependencies», in BARNES T. \& GERTLER M. (eds.), The new industrial geography. Regions, regulations and institutions, London and New York, Routledge Studies in Modern World Economy, pp. 23-53.

SUBREGIONAL PLATFORM WESTHOEK, (1998), De Westhoek, pure verwondering.

SWYNGEDOUW E. (1996), «Reconstructing citizenship, the rescaling of the state and the new authoritarianism: Closing the Belgian mines», Urban studies, 33, 8, pp. 1499-1521.

YUILL D., BATCHLER J., WISHLADE F. (1997), European regional incentives, 1997-98, $17^{\text {th }}$ edition.

ZUCKER, L., MARBY, M., ARMSTRONG, J. (1998), «Geographically Localized Knowledge: Spillovers or Markets?», Economic Inquiry, 36, 65-86.

\section{NOTES}

1. These coalitions are organized in formal (unions, employers organizations, tri-partite structures, project- and problem oriented structures: e.g., the closing of the mines in the province of Limburg) or informal (service clubs, private associations) networks.

2. The Flanders' Social and Economic Council (SERV) is a consultative body of the social partners for the Flemish government and parliament. I myself am not one of the representatives of the social partners, but within the SERV I am working for the administration where I am responsible for the regional economic policy field. At the time the platforms were introduced, I was preparing my PhD (Cabus, 1999). A critical assessment of the global-local models that are present in literature is a substantial part of this $\mathrm{PhD}$. In its essence this article confronts my views developed in the PhD in this matter with the developments in the regional economic policy field in Flanders. 
3. European structural policy is co-financed with the 4 structural funds:

* The European Fund for Regional Development (ERDF)

* The European Social Fund (ESF)

* The European Agricultural Guidance and Guarantee Fund for Agriculture (EAGGF)

* The Financial Instrument for Fisheries Guidance (FIFG)

The financial means made available through the Funds almost doubled between 1989 and 1999, rising from $0.27 \%$ of EU GDP to $0.46 \%$ (European Commission, 2001b). The transfers were most pronounced in the cohesion countries, the main beneficiaries, equivalent to over 10 years to $1.5 \%$ of GDP in Spain, 3.3\% in Portugal and 3.5\% in Greece. In Greece and Portugal, Community transfers represent over $10 \%$ of investment.

The total budget of these funds for the period 2000-2006 is 196 Billion Euro.

4. The notion subregion is introduced in order to indicate areas on a geographical scale below the formal constituent Region (Flanders).

5. As the date suggests, the platform in Antwerp was already installed before the formal decision to start with the subregional platforms. The charter for Antwerp was approved in 1999.

6. E.g., when one of the projects concerns the building up of tourist infrastructure, the administration of tourism is responsible for the realization, etc.

7. Knowing the footnotes in history regarding the installation of the subregional platforms, one of the reasons behind it was not that scientific, but had much to do with the discontentment of some political parties with the performance of the RDA's. From this viewpoint this reaction is understandable.

8. Although Porter's approach is much broader than economic factors alone, in most cases clusters get a purely economic translation.

\section{ABSTRACTS}

Actively engaging citizens is one of the main objectives behind the emergence of governance in the policy making process. The former top-down approach characterized by strong hierarchical relationships and a large distance between policy and citizens, is replaced by an approach that seeks important bottom-up (local) input. New partnerships between non-traditional and political actors are formed in the decision making process in order to engage citizens.

Since the 1990s, the governance idea has gradually become a central focus of regional development policy. One of the driving forces behind this development is certainly the politically friendly nature of global-local theory. It provides local politicians with an external enemy (the global) and a solution (the mobilization of local actors in development coalitions). From this perspective, this paper analyses the developments in Europe and especially in Flanders, where sub-regional platforms act as development coalitions.

The paper concludes that these platforms contribute to a governance structure that enables genuine public participation in policy making. At the same time, it offers a more sceptical assessment of the impact of development coalitions on economic processes. Territorial identification is a tangible outcome of the process, whilst the notion of localized knowledge spillovers is confined to academic speculation.

De burger actief betrekken bij het beleid is een van de hoofdmotieven om governance systemen op te zetten. Hierbij wordt het top down beleid dat gekarakteriseerd wordt door hiërarchische 
relaties en een grote afstand tussen het beleid en de burger, vervangen door een beleid dat in toenemende mate open staat voor een bottom up (lokale) inbreng. Om de burger te betrekken in het besluitvormingsproces ontstaan er nieuwe partnerschappen tussen politieke en andere actoren in de maatschappij.

Vanaf de jaren 1990 is een governance benadering geleidelijk aan een centrale invalshoek geworden in het regionaal-economisch beleid. Een van de drijvende krachten hierachter is zeker het beleidsvriendelijk karakter van de global-local theorie. Deze theorie geeft de lokale beleidsmakers namelijk een externe vijand (de mondiale economie) en een oplossing (de mobilisering van lokale actoren in groeicoalities). Vanuit dit perspectief analyseert deze bijdrage de ontwikkelingen in Europa en specifiek in Vlaanderen waar er streekplatformen zijn ontstaan die zich opstellen als groeicoalities voor de streek waar zij actief zijn.

Deze bijdrage besluit dat men het streekplatform inderdaad kan beschouwen als een governance structuur die een reële betrokkenheid van andere maatschappelijke actoren in het beleidsproces mogelijk maakt. Tezelfdertijd is deze bijdrage heel wat kritischer als het gaat over de reële impact van deze groeicoalities op de economie. Vastgesteld wordt dat territoriale identificatie het meest tastbare resultaat is van het proces, terwijl het concept van gelokaliseerde kennis spillovers moet beschouwd worden als academische wishful thinking.

INDEX

Keywords: governance, regional policy, subregional platforms, development coalition

Trefwoorden governance, regionaal beleid, streekplatformen, groeicoalities

\section{AUTHOR}

\section{PETER CABUS}

Institute for Social and Economic Geography, Catholic University of Leuven, Flanders' Social and Economic Council (SERV), Brussels, Belgium, pcabus@serv.be 